\title{
ТЕХНОЛОГІЯ ФОРМУВАННЯ УМІНЬ ТА НАВИЧОК САМОКОНТРОЛЮ НАВЧАЛЬНОЇ ДІЯЛЬНОСТІ СТУДЕНТІВ ВНЗ
}

\begin{abstract}
Серьогіна І. Ю. Технологія формування умінь та навичок самоконтролю навчальної діяльності студентів ВНЗ.

У статті розкрито сутність технології формування умінь та навичок самоконтролю навчальної діяльності студентів ВНЗ.

Ключові слова: самоконтроль, уміння і навички самоконтролю студентів, технологія формування умінь та навичок самоконтролю навчальної діяльності студентів.

Серегина И. Ю. Технология формирования науковець и навыков самоконтроля учебной деятельности студентов вузов.

B статье раскрыта сущность технологии формирования умений $u$ навыков самоконтроля учебной деятельности студентов вузов.

Ключевые слова: самоконтроль, умения и навыки самоконтроля, технология формирования умений и навыков самоконтроля учебной деятельности студентов.

Seregina I. Technology of teaching skills and self-learning activities of university students.

The article deals with the technology of forming skills and self-control of studying activity of university students.

Key words: self-control, ability and skills of self-control of students, technology of forming skills and self-control of studying activity of students.
\end{abstract}

Постановка проблеми. Сучасна реформа системи освіти в Україні зумовлює посилення уваги суспільства до підвищення фахової та комунікативної компетенції майбутніх фахівців. Виконання завдань, що постали перед вищою школою, вимагають пошуку шляхів удосконалення навчально-пізнавальної діяльності студентів, розроблення організаційних форм взаємодії викладача і студента. Нині можна впевнено стверджувати, що вища школа поступово переходить від передавання наукової інформації у готовому вигляді до ефективного управління самостійною та пошуковою пізнавальною діяльністю студентів, формування у них досвіду самостійного набуття знань, озброєння навичками самоконтролю, самоорганізації навчальної діяльності тощо. Адже формування у студентів стійких умінь і навичок самоконтролю навчальної діяльності як основи для свідомого оволодіння професійною діяльністю, включення у процес професійного самовдосконалення, вважаємо актуальним питанням сучасної освіти.

Аналіз наукових досліджень. Сучасна система вищої освіти покликана не лише давати студентам певний комплекс теоретичних наукових знань та практичних умінь, але й озброювати методикою самостійного контролю навчальних дій, розвитку навичок самоорганізації пізнавальної діяльності, необхідних для подальшого професійного самовизначення. Не викликає сумніву той факт, що науково обгрунтована система формування самоконтролю студентів, яка буде поступово та 
систематично організована на різного видах заняттях, дійсно стане необхідною умовою успішного навчання у ВНЗ. Грунтуючись на дослідженнях Н. Булинського, С. Гончаренко, Л. Деркач, Г. Нікіфорова, О. Савченко та інших, ми визначаємо самоконтроль у процесі навчання як усвідомлену діяльність студентів, що розглядається як система розумових дій і відбувається за їх власною ініціативою на засадах сформованих самооцінки і саморегуляції. Основною метою самоконтролю є самоперевірка результатів власної навчально-пізнавальної діяльності. Зрозуміло, що для цього необхідно створити відповідну мотивацію, сформувати уміння організовувати і контролювати свою діяльність, добирати і використовувати найбільш ефективні способи для розв'язання того чи того завдання. Із цієї позиції самоконтроль можна назвати інтелектуальним умінням, пов'язаним 3 успішним виконанням певних інтелектуальних операцій.

Проте аналіз психолого-педагогічної літератури, програмної та методичної документації дозволяє зробити висновок, що на сучасному етапі недостатньо розроблено конкретні методики ефективного розвитку самоконтролю студентів у процесі навчально-пізнавальної діяльності.

Метою статті $є$ розгляд та характеристика основних етапів технології формування умінь та навичок самоконтролю навчальної діяльності студентів BH3.

Виклад основного матеріалу. Розглянувши різні погляди науковців, у контексті нашого дослідження ми визначаємо уміння і навички самоконтролю як загальнонавчальні (навчально-інтелектуальні), які є синтезом інтелектуальних і практичних дій та зусиль учнів, спрямованих на самоорганізацію навчальнопізнавальної діяльності. Ці уміння i навички повинні бути засвоєними i закріпленими у способах діяльності у результаті управління навчальнопізнавальною діяльністю студентів. Отже, до складу умінь і навичок самоконтролю входять три компоненти (див. рис. 1.): інтелектуальний (аналіз, синтез, порівняння, узагальнення, систематизація, абстрагування, встановлення причинно-наслідкових зв'язків, постановка проблеми, іiі розв'язання, використання аналогії, уміння робити висновки, добирати аргументовані докази тощо), практичний (використання навчальної, довідкової, додаткової літератури, добір прикладів, оформлення результатів тощо), самоорганізація (планування майбутньої роботи, раціональне використовування часу і способів діяльності, регулювання дій, їх реконструкція, самоперевірка одержаних результатів, самооцінка тощо).

Власний педагогічний досвід дає змогу визначити ряд недоліків у навчальному процесі в контексті формування умінь самоконтролю: низька результативність оперативного зворотного зв'язку; недостатність урахування індивідуальних особливостей студентів; недостатнє формування умінь самоконтролю в процесі самостійної, пошукової діяльності та подальшої самоосвіти тощо. Для подолання цих недоліків нами було розроблено технологію формування умінь i навичок самоконтролю навчальної діяльності студентів ВНЗ. 


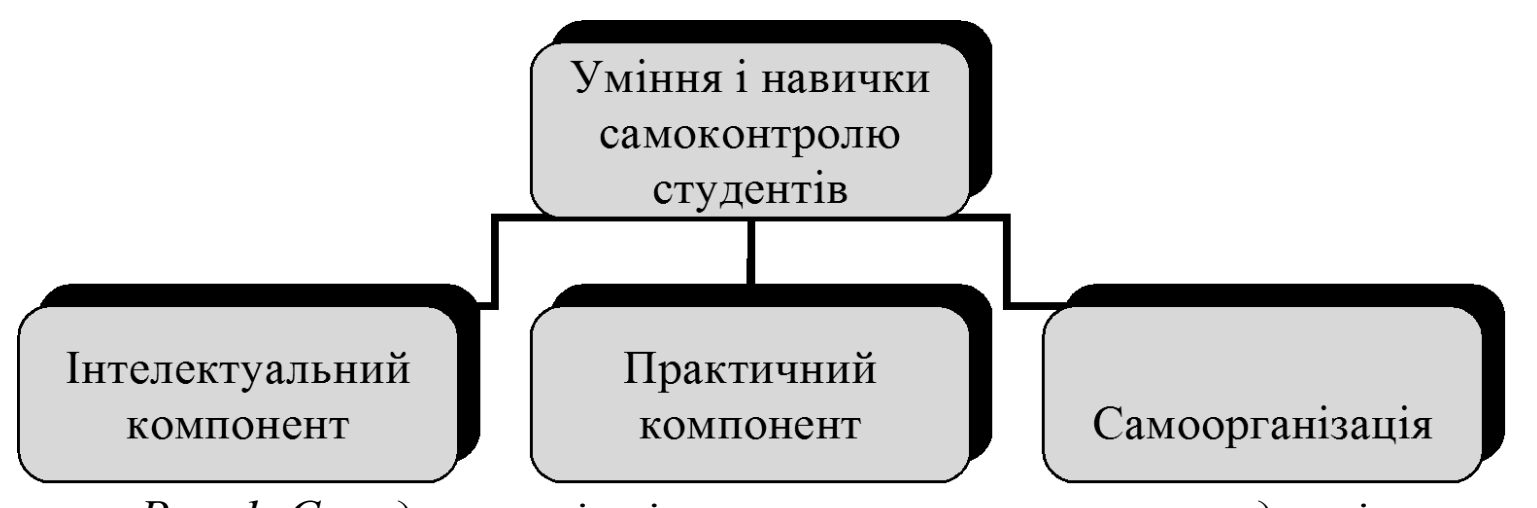

Рис. 1. Складники вмінь і навичок самоконтролю студентів

Останнім часом велика роль надається дидактичним технологіям, що покликані наповнити навчання особистісним змістом, забезпечити найбільш оптимальні умови для розв'язання поставлених завдань. Одні дослідники технологічний аспект навчання пов'язують 3 уміннями педагога впливати на особистість студента, інші вчені розуміють іiі як педагогічну техніку, маючи на увазі дидактичні, організаторські, конструктивні та комунікативні уміння. Існує i третій підхід щодо сутності вищезазначеного поняття, який передбачає керування навчально-пізнавальним процесом, організацію індивідуальної, групової та колективної навчальної діяльності.

У дослідженні ми визначаємо технологію навчання як сукупність дій, що сприяють педагогічній взаємодії між учасниками педагогічного процесу для здобуття глибоких та міцних фахових знань, практичних умінь, розвитку здібностей до подальшого самонавчання, саморозвитку тощо. Можемо виокремити такі специфічні ознаки дидактичної технології: розроблення цілей навчальної діяльності студентів на підставі результатів діагностування; орієнтація всіх навчальних дій на досягнення навчальних цілей; оперативний та якісний зворотній зв'язок; аналіз та оцінювання поточних і підсумкових результатів тощо. Так, пропонована технологія формування у студентів ВНЗ умінь і навичок самоконтролю у процесі їх навчально-пізнавальної діяльності містить п'ять універсальних етапів, а саме: орієнтаційний, інформаційний, діяльнісно-практичний, узагальнюючий та контрольний.

На першому, орієнтаційному етапі, викладач спільно зі студентами визначають мету та конкретні завдання, що розв'язуватимуться під час певної навчально-пізнавальної діяльності. Важливим кроком є структурування змісту матеріалу, на основі якого формуватимуться уміння та навички самоконтролю (змістовий аспект) та способи діяльності студентів під час опрацювання цього матеріалу (процесуальний аспект). Окрім того, педагог акцентує увагу студентів на вмінні складання різноманітних планів, тез, опорних конспектів, моделей, схем, складання різного роду інструкцій та ін.

Другим етапом запропонованої технології є інформаційно-пізнавальний, який пов'язаний із формуванням знань про уміння і навички самоконтролю, усвідомленням правил їх дії. А це потребує вияву операційного складу вмінь, які підлягають засвоєнню. Немає сумнівів у необхідності формувати 
студентів розуміння та осмислення не лише результатів своєї розумової діяльності (що є вкрай важливим у процесі здійснення самоконтролю), а й самого процесу цієї діяльності як поетапного формування розуміння: окремих фактів, явищ, подій, процесів, а також зв’язків між ними, сутності понять, ідей, механізмів, міркувань, доведень, суджень, умовиводів, які наводяться в навчальних посібниках і усному викладі викладача. Варто відзначити, що розумова діяльність не обов'язково завжди усвідомлюється студентом: у процесі пізнання відбувається взаємодія як глибоко усвідомлених словеснологічних, так й інтуїтивно-практичних, неусвідомлених компонентів. Науковцями з'ясовано, що для перенесення операцій та прийомів мислення необхідне усвідомлення узагальнень і правил розумової діяльності, а також наявність системи теоретичних знань у розв'язанні навчальних задач за засвоєними правилами та алгоритмами. Власний досвід показує, що студенти легко здійснюють самоконтроль навчання, якщо вони засвоїли абстрактні принципи, знають загальні способи дій, мають узагальнені навички розумової діяльності.

Третім етапом технології є діяльнісно-практичний, що спрямовано на практичне відпрацювання умінь самоконтролю під час фронтальної та індивідуальної навчальної, пошукової роботи зі студентами академічної групи. Основною формою роботи 3 формування умінь самоконтролю на цьому етапі $\epsilon$ навчально-пізнавальні завдання у процесі вивчення певних дисциплін у ВНЗ. Наприклад, використовування неповних рішень або рішень задач, що містять принципові проблеми в їх обгрунтуванні; складання спеціальних пам'яток, які містять правила, алгоритми до виконання певної дії, карток-консультацій; складання інструктажів (усних та письмових) тощо. Так, під час вивченні курсу «Методика виховної роботи», пропонуємо студентам варіанти таких практичних завдань у процесі опрацюванні певних тем:

1. Підготувати дискусію «Бути вихованим - що це значить?» (розробити спеціальні пам'ятки).

2. Запропонувати проект бесіди за «круглим столом» «Ми живемо, щоб залишити слід» (розробити картки-консультації).

3. Скласти план проведення тематичного усного журналу «Кривий Ріг моє місто» за допомогою алгоритму.

4. Презентація сучасних методик вивчення особистості:

- методики встановлення рівня моральної вихованості учнів. («Що ми цінуємо в людях?», «Як вчинити?», «Давайте обговоримо»);

- методика визначення рівня розвитку пізнавальних можливостей й здібностей учнів і вивчення потреб, інтересів та нахилів («Порівняй», «Перевір свою увагу»);

- методики вивчення почуттів та естетичних якостей особистості («Емоційна спрямованість», «картинна галерея»);

- методики визначення готовності школярів до трудової діяльності, профорієнтації та профконсультації («Важливі всі професії», «Батьківська порада»); 
- методики 3 нестандартним поданням завдань («Три кольори», «Неіснуюча тварина», «Що може розповісти почерк» тощо).

5. Опрацювати втілення соціальних проектів. Орієнтовні теми: «Ініціатива добрих справ», «Милосердя», «Будинок без самотності» тощо.

6. Скласти розгорнутий план проведення пізнавального вечора 3 урахуванням специфіки факультету.

7. Скласти програму з діагностування рівня вихованості учнів різних вікових груп.

На наступному етапі, узагальнювальному, відбувається формування системи умінь, усвідомлення об'єктивного взаємозв'язку усіх умінь, які у процесі пізнавальної діяльності ізольовано не застосовуються, а тільки в системі дозволяють оперувати знаннями. Цей етап також спрямовано не перетворення умінь на навички.

Останнім етапом запропонованої технології є контрольний, під час реалізації якого викладач спільно зі студентами з'ясовують, яких результатів було досягнуто в процесі формування умінь та навичок самоконтролю, які в студентів виникали труднощі, як подолати недоліки у роботі.

Висновки та перспективи подальших досліджень. Отже, аналіз результатів нашої роботи підтвердив доцільність використання запропонованої технології формування умінь та навичок самоконтролю студентів ВН3, оскільки відбулися позитивні зміни в мотиваційній сфері студентів, закріплення умінь та навичок контролювати власну навчальну діяльність та активізація пізнавальної самостійності. Перспективу подальших досліджень вбачаємо у розробленні спеціальних методичних рекомендацій, методик, спецкурсів із формування самоконтролю студентів під час вивчення певних дисциплін.

\section{Література}

1. Автомонов П. П. Технологія педагогічного успіху : [навч. посіб.] / П. П. Автомонов. - К. : Видавничо-поліграфічний центр «Київський університет», 2002. $180 \mathrm{c}$.

2. Булынский Н. Н. Особенности осуществления самоконтроля в процессе изучения общеинженерных дисциплин в вузе: В помощь преподавателю / Н. Булынский, Н. Олейник. - Челябинск : Южно-Уральский научно-образовательный центр РАО, 2001. 24 с.: табл. - Библиогр. - С. 22-23.

3. Горбунова В. С. Технология формирования и развития общих учебных умений и навыков учащихся : [метод. пособие для руководителей образовательных учреждений, методистов, учителей] / В. Горбунова, О. Левченко. - Омск : Издательство ОмГПУ, 2001. - 108 с.

4. Деркач Л. Н. Психологические основы самоконтроля учащихся в процессе обучения иностранным языкам: дис. ... д-ра психол. наук: 19.00.07 / Л. Н. Деркач. - АПН Украины; Институт психологии. - К., 1994. - 311 л.

Стаття надійшла до редакції 17.05.2012 р. 